CENDEKIA, Vol. 9, No. 1, April 2015

p ISSN: 1978 2098; e ISSN: 2407 8557; Web: cendekia.pusatbahasa.or.id

Pusat Kajian Bahasa dan Budaya, Surakarta, Indonesia

Maunah, Binti. 2015. Pendidikan dalam Perspektif Struktural Konflik.

Cendekia, 9(1): 71 78.

\title{
PENDIDIKAN DALAM PERSPEKTIF STRUKTURAL KONFLIK
}

\author{
Binti Maunah \\ IAIN Tulungagung \\ Jl. Mayor Sujadi Timur 46 Tulungagung, Jawa Timur \\ E-mail: binti_maunah@yahoo.com
}

\begin{abstract}
This article is to describe education position in the perspective of political conflicts. Library analysis is used to figure out the description, involving actual and factual references, peer-collaborators and peer-teachers teaching religion education. A round table discussion is used to finalize the conclusion. The description involves: (1) education within the conflict structure maintains that each invididual in the classroom has different opinion, needs, and interest arousing conflicts, (2) conflicts raise both negative and positive views. Positive conflicts come where sportive competition is involved and enhances students to accomplish fair superiority; in reserve, negative conflicts are destructive, (3) negative conflicts in the classroom may be positive if teachers implements good management conflicts well.
\end{abstract}

Keywords: education, political structure, conflict management.

Pendidikan menghadapi berbagai problem yang sangat komplek dalam kehidupan masyarakat saat ini. Globalisasi yang melanda dunia yang diikuti dengan perkembangan teknologi dan ilmu pengetahuan yang sangat pesat, telah menyebabkan terjadinya perubahan di segala bidang. Dengan adanya perubahan itu dunia pendidikan diharuskan dan dituntut dapat memberikan kontribusi riil yang berupa kemampuan peningkatan kualitas hasil, pelayanan pendidikan, dan pengabdian kepada masyarakat.

Pemikiran perspektif konflik menekankan perbedaan-perbedaan dan perpecahan pada masing-masing kelompok yang terstuktur antar-berbagai individu dan kelompok yang memunculkan terbentuknya hubungan-hubungan pribadi dalam suatu sistem sosial. Dengan demikian, masyarakat menjadi terpecah-pecah. Mereka terbelah menjadi kelompok yang memiliki kekuatan dan mereka yang merasa tidak memiliki kekuatan. Di dalam masyarakat juga terjadi pembagian kelas atau kelompok. Ada kelas-kelas sosial yang mempunyai kekuatan-kekuatan yang mampu memenuhi kebutuhan-kebutuhan mereka sehari-hari. Ada juga kelas yang didominan, dieksploitasi dan disubordinasi (Wulandari, 2006).

Dalam perspektif konflik, masyarakat mempunyai kebutuhan (interest) yang sifatnya unik dan langka. Individu yang mempunyai perbedaan dalam hal keberhasilan mendapatkan kebutuhan primer (makan, minum, pangan, sandang, papan), rasa aman, bersosialisasi, dan aktualisasi. Hal ini disebabkan karena individu satu dengan yang lain mempunyai kemampuan yang berbeda pula. Hal inilah yang menyebabkan terjadinya konflik secara mendasar.

Konflik merupakan salah satu gejala sosial yang selalu datang dan selalu ada dalam kehidupan sosial, sehingga konflik mempunyai sifat yang disebut dengan istilah inheren. 
CENDEKIA, Vol. 9, No. 1, April 2015

p ISSN: 1978 2098; e ISSN: 2407 8557; Web: cendekia.pusatbahasa.or.id

Pusat Kajian Bahasa dan Budaya, Surakarta, Indonesia

Maunah, Binti. 2015. Pendidikan dalam Perspektif Struktural Konflik.

Cendekia, 9(1): 71 78.

Maksudnya, konflik selalu berada dalam kehidupan sosial. Adapun yang memotivasi adanya konflik dan integrasi adalah perbedaan dan persamaan di dalam kepentingan sosial.

Di bidang pendidikan juga selalu terjadi konflik, baik antara siswa dengan siswa, siswa dengan guru, guru dengan guru, guru dengan kepala sekolah, dan konflik lainnya. Khusus di dalam kelas, selalu tejadi konflik antar siswa. Melalui studi ini, diharapkan dapat dirumuskan bagaimana guru menciptakan konflik yang konstruktif, mengelola konflik yang ada, dan membangun budaya konflik yang tidak destruktif.

\section{METODE}

Metode yang digunakan dalam penulisan studi ini adalah kepustakaan. Data primer diperoleh dari pembacaan buku-buku mutakhir. Kajian dilakukan pada bulan November 2014 dengan melibatkan teman sejawat dari tim guru pendidikan agama Islam. Pada tahap awal, penulis berupaya mengumpulkan materi darii berbagai teori konflik yang berkembang, kemudian disusun dalam bentuk naskah teks yang siap dibahas dalam peer group. Berdasarkan hasil diskusi round table dan berbagai masukan, kemudian naskah kajian diperbaiki, untuk dibahas pada diskusi tahap kedua. Hasil akhir diskusi kedua naskah kajian difinalisasi dan siap dipublikasikan dalam sekala yang lebih luas.

\section{HASIL DAN BAHASAN \\ Hakikat Pendidikan}

Pendidikan dari segi etimologis berasal dari bahasa Yunani "Paedagogike". Pendidikan merupakan kata majemuk "pais" yang berarti "Anak" dan "Ago" yang berarti "Aku membimbing". Jadi, Paedagogike artinya aku membimbing anak (Hadi, 2005:27). Adapun rumusan pendidikan mempunyai inti: pendidikan adalah pemanusiaan anak dan pendidikan adalah pelaksanaan nilai-nilai (Driyarkara, 1980:18).

Dalam pengertian yang sederhana dan umum, makna pendidikan sebagai usaha manusia untuk menumbuhkan dan mengembangkan potensi-potensi pembawaan, baik jasmani maupun rohani sesuai dengan nilai-nilai yang ada dalam masyarakat dan kebudayaan. Dengan kata lain, pendidikan harus mampu mendidik manusia menjadi manusia.

Pendidikan merupakan sebagai proses perkembangan kecakapan seseorang dalam bentuk sikap dan perilaku yang berlaku dalam masyarakat dan proses sosial di mana seseorang dipengaruhi oleh suatu lingkungan yang terpimpin misalnya sekolah sehingga dia dapat mencapai kecakapan sosial dan mengembangkanya.

Menurut Undang-undang Sisdiknas No. 20 tahun 2003, pendidikan adalah usaha sadar dan terencana untuk mewujudkan suasana belajar dan pross pembelajaran agar peserta didik secara aktif mengembangkan potensi dirinya untuk memiliki kekuatan spiritual keagamaan, pengendalian diri, kepribadian, kecerdasan, akhlak mulia, serta ketrampilan yang diperlukan dirinya dan masyarakat (Undang-Undang RI No. 20 Tahun 2003).

Tujuan Pendidikan merupakan salah satu faktor yang terpenting di dalam pendidikan, karena tujuan adalah merupakan salah satu arah yang hendak dicapai atau yang hendak dituju oleh pendidikan. Begitu juga dengan penyelenggaraan pendidikan yang tidak dapat dilepaskan dari sebuah tujuan yang hendak dicapaianya. Tujuan pendidikan adalah meningkatkan derajat kemanusiaan manusia (Tafsir, 2006:47). 
CENDEKIA, Vol. 9, No. 1, April 2015

p ISSN: 1978 2098; e ISSN: 2407 8557; Web: cendekia.pusatbahasa.or.id

Pusat Kajian Bahasa dan Budaya, Surakarta, Indonesia

Maunah, Binti. 2015. Pendidikan dalam Perspektif Struktural Konflik.

Cendekia, 9(1): 71 78.

Adapun tujuan pendidikan nasional secara formal di Indonesia telah beberapa kali mengalami perumusan atau perubahan, dan rumusan tujuan pendidikan nasional yang terakhir seperti disebutkan dalam Undang-Undang RI No. 20 Tahun 2003 tentang SISDIKNAS Bab II Pasal 3 adalah berkembangnya potensi peserta didik agar menjadi manusia-manusia yang beriman dan bertaqwa kepada Tuhan yang Maha Esa, berakhlak mulia, sehat dan berilmu, cakap, kreatif, mandiri dan menjadi warga negara yang demokratis serta bertanggung jawab.

Tujuan pendidikan nasional perumusannya dapat memberikan arah yang jelas bagi setiap usaha pendidikan di negara Republik Indonesia. Untuk dapat mencapai tujuan pendidikan nasional tersebut, dibutuhkan adanya lembaga-lembaga pendidikan yang masingmasing mempunyai tujuan tersendiri, yang selaras dengan tujuan nasional. Oleh karena itu, setiap usaha pendidikan di Indonesia tidak boleh bertentangan dengan tujuan pendidikan nasional, bahkan harus menopang atau menunjang tercapainya tujuan tersebut. (Zuhairini, Abdul Ghofir, 2002).

Perumusan tersebut menunjukkan bahwa pendidikan mempunyai tujuan utama yaitu menjadikan manusia yang bagus, kuat dalam ilmu pengetahuan, sikap serta keterampilan. Pendidikan mempunyai harapan terlaksana dengan adanya perencanaan dalam proses pembelajaran bagi individu agar berkembang dan tumbuh menjadi manusia akhlak yang mulia, berilmu, beramal, bertanggungjawab, kreatif dan mandiri, baik dari aspek rohani maupun jasmani yang terkenal dengan "al aqlussalim fijismissalim" bahwa akal yang sehat itu berada pada jiwa yang sehat.

Pendidikan usia dini (PAUD) maupun Taman Kanak-Kanak (TK), anak-anak Indonesia sudah harus mulai diajarkan materi agama di sekolah, ketika usia SD/MI sampai Perguruan Tinggi (PT), tetap diharuskan ada mata kuliah Civic Education. Tetapi riil di lapangan kita masih banyak melihat para siswa mencontek, curang, bolos, tawuran antar siswa, ngebut-ngebutan.

Dalam rangka melakukan dan membangun penguatan peserta didik harus memperhatikan dan mensinergikan beberapa yang terkait dengan pendidikan yaitu; orang tua, masyarakat, pemerintah sekolah sehingga dapat memecahkan bersama jika terdapat masalahmasalah atau gejala-gejala negatif, antara lain mempunyai keinginan menyendiri, malas, jenuh, gelisah, kurang percaya diri, tertarik kepada lawan jenis, rasa malu yang berlebihan, kurang adanya kemauan untuk bekerja, adanya pertentangan sosialdan suka mengkhayal. Adanya gejala-gejala negatif yang ada pada remaja pada umumnya, pendidik dalam hal ini guru dan dosen juga orang tua seharusnya menyadari dan melakukan upaya perbaikan perlakuan sikap terhadap anak dalam proses pendidikan nonformal maupun formal.

\section{Pendidikan dalam Perspektif Struktural Konflik}

Pendidikan dalam struktural konflik dimulai dengan menelusuri pemikiran perspektif stuktural konflik. Teori struktural konflik muncul sebagai pengritik utama struktural fungsional (Rifa'i, 2011:189).

Adapun resolusi konflik mulai berkembang era pasca perang dingin. Mengenai penyelesaianya selalu berhadapan dengan tantangan-tantangan yang sangat fundamental. Bidang ini mulai muncul pada tahun 1950-an dan 1960-an, pada puncak Perang Dingin, 
CENDEKIA, Vol. 9, No. 1, April 2015

p ISSN: 1978 2098; e ISSN: 2407 8557; Web: cendekia.pusatbahasa.or.id

Pusat Kajian Bahasa dan Budaya, Surakarta, Indonesia

Maunah, Binti. 2015. Pendidikan dalam Perspektif Struktural Konflik.

Cendekia, 9(1): 71 78.

ketika pengembangan senjata nuklir dan konflik antara adikuasa tampaknya mengancam kelangsungan hidup manusia. (Oliver, dkk, 2002).

Teori konflik berpendapat bahwa kehidupan sosial di masyarakat terdapat berbagai bentuk pertentangam. Paksaan dalam wujud hukum dipandang sebagai faktor utama untuk memelihara lembaga-lembaga sosial, seperti milik pribadi (property), perbudakan (slavery), kapital yang menimbulkan ketidaksamaan hak kesamaan. Kesenjangan sosial terjadi dalam masyarakat karena bekerjanya lembaga paksaan tersebut yang bertumpu pada cara-cara kekerasan, penipuan dan penindasan. Dengan demikian, titik tumpu dari konflik sosial adalah kesenjangan sosial.

Konflik sosial adalah pertentangan antara segmen-segmen masyarakat untuk memperebutkan aset-aset yang bernilai. Jenis dari konflik antara individu, konflik antar kelompok, dan bahkan antar bangsa. Tetapi bentuk konflik yang paling menonjol menurut Mark adalah konflik yang disebabkan oleh cara produksi barang-barang yang material.

Karl Mark memandang masyarakat terdiri dari dua kelas yang didasarkan pada kepemilikan sarana dan alat produksi yaitu kelas borjuis dan proletar (Elly, 2011:348). Teori ini terkenal dengan teori Fungsional konflik, yang menekankan fungsi konflik bagi sistem sosial atau masyarakat (Poloma, 1994:113).

Konflik merupakan proses yang bersifat instrumental dalam pembentukan, penyatuan dan pemeliharaan struktur sosial. Konflik dapat memperkuat antara kelompom satu dengan kelompok yang lain agar tidak menyatu dengan kelompok yang ada di sekitarnya. Coser membagi dua kelompok.

Pertama, konflik realitas, berasal dari kekecewaan terhadap tuntutan-tuntutan khusus bahwa yang terjadi dalam hubungan dan perkiraan kemungkinan keuntungan para partisipan dan yang ditujukan pada obyek yang dianggap mengecewakan.

Kedua, konflik nonrealistis adalah, konflik yang bukan berasal dari tujuan-tujuan yang antagonis, tetapi dari kebutuhan untuk meredakan ketegangan, paling tidak dari salah satu pihak. Dalam kelompok masyarakat yang telah maju membuat "kambing hitam" sebagai pengganti ketidakmampuan melawan kelompok yang seharusnya menjadi lawan mereka (Poloma, 1994:113).

Menurut Coser, konflik dapat bersifat fungsional positif maupun negatif. Fungsional positif apabila konflik melawan struktur. Dalam kaitan dengan sistem nilai yang ada di masyarakat, konflik dapat bersifat fungsional apabila menyerang suatu nilai inti (Soetomo, 1986:35). Selanjutnya Coser mengatakan bahwa konflik seringkali disebabkan oleh adanya kelompok masyarakat lapisan bawah yang semakin mempertanyakan legitimasi tersebut diakibatkan oleh kecilnya saluran untuk menyampaikan keluhan-keluhan yang ada (Turner, 1991).

Berdasarkan pemikiran Coser tersebut diatas, secara teoritis dapat dijelaskan bahwa kekerasan yang terjadi bisa disebabkan oleh adanya isu-isu yang tidak realistis, isu tidak realistis adalah isu yang tujuanya tidak dapat direalisir. Coser mencontohkan isu tentang agama, etnis dan suku merupakan sesuatu yang tidak realistis. Konflik yang terjadi karena isu tersebut dikonsepsikan akan berlangsung secara keras (Halcvy, Etzioni, Eva and Amitai Etzioni, 1973). 
CENDEKIA, Vol. 9, No. 1, April 2015

p ISSN: 1978 2098; e ISSN: 2407 8557; Web: cendekia.pusatbahasa.or.id

Pusat Kajian Bahasa dan Budaya, Surakarta, Indonesia

Maunah, Binti. 2015. Pendidikan dalam Perspektif Struktural Konflik.

Cendekia, 9(1): 71 78.

Plerre van dea Bergine dalam Ritzer (1992:28) mencoba mempertemukan kedua teori struktural fungsional dan teori konflik, yang menunjukkan beberapa persamaan analisa yaitu sama-sama bersifat holistik, dalam arti sama-sama melihat masyarakat sebagai bagian yang saling berkaitan satu dengan yang lainya, dan perhatian utamanya ditunjukkan kepada adanya hubungan antar bagian-bagian. Kedya teori tersebut mengakui bahwa konflik dapat memberikan sumbangan terhadap integhrasi, dan sebaliknya integrasi dapat pula melahirkan konflik.

Pusat perhatian Turner pada konflik adalah sebagai proses dari peristiwa-peristiwa yang mengarah kepada interkasi yang disertai kekerasan antara kedua kelompok bahkan bisa lebih. Turner membagi 9 tahapan untuk menuju konflik secara terbuka (Elly, 2011:371). Adapun sembilan tahap itu adalah: 1) Sistem sosial terdiri dari unit-unit atau kelompokkelompok itu terdapat ketidak seimbangan pembagian kekuasaan atau sumber-sumber penghasilan. 2) Unit-unit ataupun kelompok itu terdapat ketidak seimbangan dalam pembagian kekuasaan maupun sumber-sumber penghasilan. 3) Kelompok-kelompok yang tidak mempunyai kekuasaan maupun sumber penghasilan mulai mempertanyakan legitimasi sistem tersebut. 4) Legitimasi itu membawa mereka kepada kesadran bahwa mereka harus mengubah sistem alokasi kekuasaan atau sumber-sumber penghasilan itu demi untuk memenuhi keentingan kelompok. 5) Kesadaran itu menyebabkan mereka secara emosional terpancing untuk marah. 6) Kemarahan tersebut seringkali meledak begitu saja atas cara yang tidak terorganisir. 7) Keadaan yang demikian menyebabkan mereka semakin tegang. 8) Ketegangan yang semakin hebat menyebabkan mereka mencari jalan untuk mengorganisisr diri guna melawan kelompok yang berkuasa. 9) Akhirnya konflik terbuka bisa terjadi antara kelompok yang berkuasa dan tidak berkuasa. Tingkatan kekerasan dalam konflik sangat tergantung kepada kemampuan masing-masing pihak yang bertikai untuk mendefinisikan kembali kepentingan mereka secara obyektif atau kemampuan masing-masing pihak menanggapi, mengatur, dan mengontrol konflik itu.

Menurut Ralf Dahrendof masyarakat dibagi menjadi dua kelompok, yaitu kelompok dasar pendidikan kewenangan (authority), yaitu kelas yang memiliki kewenangan (dominan) dan kelas yang tidak memiliki kewenangan (subyeksi): 1) Setiap kehidupan sosial berada dalam proses perubahan, sehingga perubahan merupakan gejala yang bersifat permanen yang mengisi setiap perubahan kehidupan sosial. Gejala perubahan kebanyakan sering diikuti oleh konflik baik secara personal maupun secara interpersonal. 2) Setiap kehidupan sosial selalu terdapat konflik didalam dirinya sendiri, oleh sebab itu konflik merupakan gejala yang permanen yang mengisis setiap kehidupan sosial. Gejala konflik akan berjalan seiring dengan kehidupan sosial itu sendiri, sehingga lenyapnya kehidupan sosial. 3) Setiap elemen dalam kehidupan sosial memberikan andil bagi pertumbuhan dan variabel yang saling berpengaruh. Elemen-elemen tersebut akan selalu dihadapkan pada persamaan dan perbedaan. Sehingga persamaan akan mengantarkan pada akomodasi sedangkan perbedaan akan mengantarkan timbulnya konflik. 4) Setiap kehidupan sosial, masyarakat akan terintegrasi di atas penguasaan atau dominasi sejumlah kekuatan-kekuatan lain. Dominasi kekluatan secara berpihak akan menimbulkan konsiliasi, akan tetapi memandang simpanan benih-benih konflik yang bersifat laten, yang sewaktu-waktu akan meledak menjadi konflik terbuka (Elly, 2011:369-370). 
CENDEKIA, Vol. 9, No. 1, April 2015

p ISSN: 1978 2098; e ISSN: 2407 8557; Web: cendekia.pusatbahasa.or.id

Pusat Kajian Bahasa dan Budaya, Surakarta, Indonesia

Maunah, Binti. 2015. Pendidikan dalam Perspektif Struktural Konflik.

Cendekia, 9(1): 71 78.

Konflik memiliki perspektif yang berbeda dengan perspektif fungsional karena melihat kontribusi yang positif kepada lembaga pendidikan dalam masyarakat. Dalam perspektif ini terdapat penekanan-penekanan adanya perbedaan yang sangatmenyolok yang ada pada setiap diri individu dalam mendukung suatu sistem sosial. Konflik menunjukkan adanya perbedaan pada masing-masing individu disebabkan karena mempunyai kebutuhan yang sangat terbatas. Adapun kemampuan untuk memenuhi kebutuhan individu tersebut saling berbeda satu dengan yang lainya.

Teori konflik berpandangan perubahan sosial terjadi melalui proses penyesuaian nilainilai yang berdampak pada perubahan dan menghasilkan kompromi-kompromi yang berbeda dengan kondisi semula. Proses konflik bersifat instrumental dalam penyatuan, pemeliharaan dan pembentukan dalam struktur sosial.

Konflik kekerasan dan kerusuhan sosial bernuansa agama, rasa dan antar golongan yang mengiringi krisis ekonomi-politik pada waktu yang lalu, menunjukkan betapa rapuhnya relasi antar agama antar etnik yang kita bangun dan kita banggakan selama ini (Soleh Isre, 2003:iii). Adapun hal-hal yang menyebabkan munculnya konflik antara lain: 1) Konflik diri sendiri dengan seseorang dapat terjadi karena perbedaan peranan, kepribadian dan kebutuhan. 2) Konflik diri sendiri dengan kelompok dapat terjadi karena individu tersebut mendapat tekanan, atau individu bersangkutan telah melanggar norma-norma kelompok sehingga dimusuhi atau dikucilkan oleh kelompoknya. 3) Konflik terjadi karena adanya suatu ambisi salah satu kelompok untuk berkuasa. (Husaini Usman, 2006:389).

Dari cara menghadapi dan menyelesaikan konflik sosial dapat diklasifikasikan: 1) Konflik kalah versus kalah. Dalam sebuah konflik pasti terdapat pihak-pihak yang saling berselisih dan melakukan aksi saling mengalahkan, menyingkirkan atau melenyapkan. Dalam hal ini masing-masing pihak saling kalah, jadi berakhir saling kalahnya kedua pihak. 2) Konflik kalah versus menang. Konflik akan berakhir dalam bentuk kalah versus menang apabila salah satu pihak yang bertikai mencapai keinginanya dengan mengorbankan keinginan pihak lain. 3) Konflik menang versus menang. Konflik akan berakhir menang versus menang jika pihak-pihak yang berkaitan bersedia satu sama lain untuk mencapai kesepakatan baru yang saling menguntungkan (Usman, 2006:389).

Untuk memahami Stratifikasi Sosial harus melihat teori kelas yaitu" manusia semenjak nabi Adam sampai sekarang mempunyai sejarah pertikaian dan konflik antar klas. Hubungan manusia terjadi adanya hubungan posisi masing-masing terhadap sarana produksi.

Teori konflik mempunyai implikasi kepada pendidikan di masyarakat dan strategi perencanaan antara lain: 1) membebaskan kurikulum dari idiologi yang mendominasi, 2) menciptakan pendidikan yang tertib, herarkhis dan kondusif tanpa dipengaruhi struktur sekolah, 3) konflik dan eksploitasi, 4) kekuatan maupun kekuasaan yang dapat menciptakan ketertiban sosial, 5) mengembangkan pendidikan yang dapat membebaskan, dan 6) memperrjuangkan kelas secara terus menerus.

Dalam teori konflik nampak jelas didominasi oleh kaum borjuis sebagai pemegang kendali maupun kebijkan dan keputusan, mereka dengan mudah mendapatkan stratifikasi sosial dalam masyarakat, demikian dalam dunia pendidikan, karena yang dapat mengendalikan adalah status ekonomi. 
CENDEKIA, Vol. 9, No. 1, April 2015

p ISSN: 1978 2098; e ISSN: 2407 8557; Web: cendekia.pusatbahasa.or.id

Pusat Kajian Bahasa dan Budaya, Surakarta, Indonesia

Maunah, Binti. 2015. Pendidikan dalam Perspektif Struktural Konflik.

Cendekia, 9(1): 71 78.

Dalam stratifikasi sosial kita mengenal bahwa klas bawah tidak akan mempunyai dan memperoleh pendidikan dibandingkan dengan kelas menengah dan tinggi. Contoh dalam hal ini adalah kelas tinggi tidak akan dapat dipahami oleh kelas tengah dan kelas bawah, dikarenakan pengalaman yang diperolehnya sangat berbeda satu dengan yang lainya. Realita menunjukkan bahwa pendidikan ditentukan oleh penguasa, sehingga kebijakan untuk mendapatkan kesempatan dalam mengenyam pendidikan dan keilmuan kurang bahkan tidak sesuai dengan yang kita harapkan, sekaligus buka bagian dari keinginan pesesrta didik dan bidang kompetensinya.

Uraian di atas dapat memberikan informasi bahwa pendidikan dalam struktural konflik melihat bahwa setiap individu di dalam kelas mempunyai perbedaan pendapat, kepentingan, dan keinginan yang dapat memunculkan konflik. Sebagaimana diketahui, kelas yang ada saat ini berisi siswa dari multikultur atau multi etnis. Bahkan, kelas yang ada saat ini juga multi budaya, multi agama, multi gender, multi ras, multi umur, dan multi tingkat kecerdasan. Oleh karena itu, sangat wajar akan mudah terjadi konflik.

Konflik dapat berakibat posisit dan negatif. Konflik di dalam kelas bersifat positif manakala terjadi persaingan yang sehat antarsiswa. Siswa saling berlomba untuk menjadi yang terbaik. Mereka saling berlomba untuk menjadi juara satu. Ketika hal itu yang terjadi, guru perlu membuat konflik agar terjadi persaingan siswa secara rasional

Konflik di kelas dalam arti negatif, akan menimbulkan persaingan yang tidak sehat dengan saling menjatuhkan antara siswa yang satu dengan lainnya. Menyontek adalah salah satu contoh konflik yang tidak fair. Mengapa hal itu dikatakan tidak fair karena siswa yang sudah belajar dengan baik, bisa jadi nilainya kalah dengan siswa yang berhasil menyontek dan tidak terdeteksi oleh guru.

Konflik dapat diciptakan, dikelola, dan bahkan dicegah. Konflik negatif yang terjadi di kelas dapat menjadi positif manakala guru mampu mengelola konflik dengan baik. kemampuan guru dalam mengelola konflik menjadi tumpuhan manakala menghendaki proses belajar mengajar dapat berjalan dengan baik. Ketika guru tidak mampu mengelola konflik dengan baik, maka konflik yang terjadi antar siswa menjadi kontra produktif, merusak, tidak konstruktif, dan merugikan semua pihak. Oleh kerana itu, seluruh guru hendaknya mampu mengelola konflik yang terjadi di kelas dengan baik.

\section{SIMPULAN}

Berdasarkan uraian di atas dapat disimpulkan bahwa:

1) pendidikan adalah usaha sadar dan terencana untuk mewujudkan suasana belajar dan pross pembelajaran agar peserta didik secara aktif mengembangkan potensi dirinya untuk memiliki kekuatan spiritual keagamaan, pengendalian diri, kepribadian, kecerdasan, akhlak mulia, serta ketrampilan yang diperlukan dirinya dan masyarakat

2) pendidikan dalam struktural konflik melihat bahwa setiap individu di dalam kelas mempunyai perbedaan pendapat, kepentingan, dan keinginan yang dapat memunculkan konflik,

3) Konflik dapat berakibat posisit dan negatif. Konflik di dalam kelas bersifat positif manakala terjadi persaingan yang sehat antarsiswa, sehingga saling berlomba untuk 
CENDEKIA, Vol. 9, No. 1, April 2015

p ISSN: 1978 2098; e ISSN: 2407 8557; Web: cendekia.pusatbahasa.or.id

Pusat Kajian Bahasa dan Budaya, Surakarta, Indonesia

Maunah, Binti. 2015. Pendidikan dalam Perspektif Struktural Konflik.

Cendekia, 9(1): 71 78.

menjadi juara. Konflik di kelas dalam arti negative, akan menimbulkan persaingan yang tidak sehat dengan saling menjatuhkan antara siswa yang satu dengan lainnya,

4) konflik negatif yang terjadi di kelas dapat menjadi positif manakala guru mampu mengelola konflik dengan baik.

\section{DAFTAR RUJUKAN}

Damsar, 2011. Sosiologi Pendidikan, Jakarta: Kencana

Djumberansyah, M. 2004. Pengantar Filsafat Pendidikan, Malang: Bayu Media Publishing

Driyakarya, 1980. Ilmu Tentang Pendidikan, Yogyakarta: Yayasan Kanisius

Elly M, Setiadi dan Usman Kolip, 2011. Pengantar Sosiologi, Jakarta: Kencana

George, Ritzer, 1992. Sosiologi Ilmu Pengetahuan Berparadigma Ganda,

Penyadur: Ali Mandan, Jakarta: CV. Rajawali Press.

Ghofir, Zuhairini Abdul, 2001. Metodologi Pembelajaran Pendidikan Agama Islam, Malang: UM Press

Halcvy, Etzioni, Eva and Amitai Etzioni, 1973. Social Change : Sources, Patterns and Consequences, New York: Basic Books, Inc.

Husaini Usman, 2006. Manajemen Teori, Praktik, dan Riset Pendidikan, Jakarta: Bumi Aksara

Kartono, Kartini, 1992. Pengantar Ilmu Pendidikan Teoritis, Bandung: Mandar Maju.

Maliki, Zainudddin, 2005. Sosiologi Pendidikan, Yogyakarta: UGM Press.

Miall, Hugh; Oliver dkk, 2002. Resolusi Damai Konflik Kontemporer,

Menyelesaikan, Mencegah, Mengelola dan Mengubah Konflik Bersumber Politik Sosial, Agama dan Ras, Terj. Jakarta: PT Raja Grafindo Persada.

Nasution, S. 2004. Sosiologi Pendidikan. Jakarta: Bumi Aksara.

Poloma, Margaret, M. 1994. Sosiologi Kontemporer, Jakarta: PT. Raja Grafindo Persada

Republik Indonesia, Undang-Undang RI No 20 Tahun 2003 tentang Sistem Pendidikan Nasional, Bandung: Citra Umbara.

Rifa'i, Muhammad, 2011. Sosiologi Pendidikan, Jakarta: Kencana.

Ritzer, George. 1992. Sosiology Ilmu Pengetahuan Berparadigma Ganda, Penyadur Ali Mandan, Jakarta: Rajawali Press

Setiadi, Elly, dan Usman Kolip, 2011. Pengantar Sosiologi, Jakarta: Kencana.

Soedomo Hadi, 2005. Pendidikan Suatu Pengantar, Surakarta: LPP UNS dan UNS Press

Soetomo, 1986. Masalah Sosial dan Pembangunan, Jakarta: LP3ES

Soleh, Moh, 2005. Konflik Etna Religius Indonesia Kontemporer, Jakarta: Departemen Agama RI.

Tafsir, Ahmad, 2006. Filsafat Pendidikan Islam: integrasi Jasmani, Rohani Dan Kalbu Memudahkan Manusia, Bandung: PT Remaja Rosdakarya.

Turner, Bryan S, 1991. Religion and Social Theory, London: Sage Publication.

Usman, Husaini, 2006. Manajemen Teori, Praktik, dan Riset Pendidikan, Jakarta: Bumi Aksara

Wulandari, Dewi, 2006. Sosiologi Konsep dan Teori, Bandung: PT Refika Aditama.

Zeitlin, Irving M. 2009, Memahami Kembali sosiologi, Yogyakarta: UGM Press 